\title{
Marine Quality Assessment of Northern Lebanese Coast: Microbiological and Chemical Characteristics and their Impact on the Marine Ecosystem
}

\author{
R.El Fallah ${ }^{1}$, Z. Olama ${ }^{2 *}$ and H. Holail ${ }^{3}$ \\ ${ }^{1}$ Department of Biological and Environmental Sciences Faculty of Science, \\ Beirut Arab University, Debbieh, Lebanon \\ ${ }^{2}$ Department of Botany and Microbiology, Faculty of Science, Alexandria University, Egypt \\ ${ }^{3}$ Azm University, Tripoli, Lebanon \\ *Corresponding author
}

\section{A B S T R A C T}

\section{Keywords}

Trace metals, Ionic

composition, Water quality,

Bacterial contamination, Sediment contamination, Assessment

\section{Article Info}

Accepted: 16 December 2015 Available Online: 10 January 2016
The present work was conducted to study the physical, chemical and microbiological characteristics of the marine water along the Mina coastline in Tripoli city Northern Lebanon, in order to assess its quality and its impact on the marine ecosystem. Physico-chemical parameters and heavy metals concentrations were determined using standard analytical procedure. The results of the physicochemical analysis were obtained in the following range during June and November respectively; temperature $\left(24-25^{\circ} \mathrm{C}\right),\left(24-24.8^{\circ} \mathrm{C}\right) ; \mathrm{pH}$ (5.25-8.75), (4.2-8.45); dissolved oxygen $(1.38-7.8 \mathrm{mg} / \mathrm{L}),(2.01-7.8 \mathrm{mg} / \mathrm{L})$; electrical conductivity (26.7$1500 \mathrm{~ms} / \mathrm{cm}),(43.1-1650 \mathrm{~ms} / \mathrm{cm})$ total dissolved solids $(17355-975000 \mathrm{ppm})$, (280150-1072500 ppm). Chemical analysis of seawater samples has shown that the values of the ionic concentrations in non-contaminated areas were in accordance with the international standard for sea. Trace metals concentrations $(\mathrm{mg} / \mathrm{l})$ were evaluated, $\mathrm{Cr}, \mathrm{Cu}$ and $\mathrm{Pb}$ recorded values high levels that exceeded the TRV. Results of microbial analysis for heterotrophic bacteria, total and fecal coliform, Salmonella sp and Shigella sp indicated significant levels of pollution indicating pollution from untreated sewage. To study the risk assessment, sediment samples were analyzed for the detection of trace metals concentrations. Results showed that 3 out of 23 sites showed high value of contamination factor whereas the rest of the sites showed average values below the guideline.

\section{Introduction}

Lebanon has few kilometers (about $220 \mathrm{~km}$ ) of shoreline lying along the northern segment of the eastern Mediterranean. Tripoli is the second largest city in Lebanon, with a population of about 400000 people. Like other coastal stretches, urbanization and development projects are rapidly overtaking the area (Awad and Darwish, 2009).Water quality is defined in terms of the chemical, physical and biological contents of water (Lawson, 2011). Coastal areas are potentially affected by large and 
relatively constant inflows from contaminated water sources like rivers or inadequately treated sewage (Lees, 2000; Lipp et al., 2001).The dynamic balance in the aquatic ecosystem is upset by human activities, resulting in pollution which is manifested dramatically as fish kill, offensive taste, odor, color and unchecked aquatic weeds (Adefemi and Awokunmi, 2010). The accurate determinations of heavy metals and other physical and chemical parameters in aquatic environment are of ultimate importance for controlling their pollution. Marine waters and sediments, particularly those receiving anthropogenic inputs, contain a multitude of chemical contaminants that are potentially toxic to aquatic organisms (Krahn et al., 1984). In the Lebanese Northern coastline, wastewater treatment has been neglected to a certain extent. The lack of operational and efficient wastewater treatment plants makes wastewater the main source of pollution of the coastal zone of Tripoli city. Most of the wastewater is discharged untreated or partially treated along the shoreline.

\section{Materials and Methods}

\section{Sampling}

Water samples were collected from 45 locations along the Mina city's coast, during June and November 2012 following the global positioning system (GPS) (Fig. 1). Seawater samples were filtered. All samples were collected in sterile bottles following the protocol for aseptic sampling technique (Mansilha et al., 2009) and were immediately transported to the laboratory and processed within 2-3 $\mathrm{h}$ of collection. The sampling bottles were pre-conditioned with 5\% nitric acid and later rinsed thoroughly with distilled de-ionized water. At each sampling site, the polyethylene sampling bottles were rinsed at least three times before sampling was done. Precleaned polyethylene sampling bottles were immersed about $10 \mathrm{~cm}$ below the water surface (Öztürk et al., 2009).The water samples for atomic absorption spectroscopy (AAS) were acidified prior to analysis with a few drops of $\mathrm{HNO}_{3}$ to keep the metals in solution (Krasniki et al., 2010). For microbiological analyses, water samples were collected in a 100 sterile plastic screw capped bottles under aseptic technique and preserved at $-5^{\circ} \mathrm{C}$.

Twenty sediment samples were collected during June 2012 from different locations following GPS near the sea shore along the coast of Mina city in June 2012, at $10 \mathrm{~cm}$ depth from soil surface, to be analyzed for the concentration in heavy metals (Fig. 2). Samples were taken with a tool prototype of the van Veen grab, and the upper 3-5 cm of sediment were removed with a PTFE spatula (Pekey, 2004) and were maintained in polyethylene bags, refrigerated, and returned to the laboratory (ASTM, 1990).

\section{Field Analysis}

Several physico-chemical parameters were measured in situ including temperature and $\mathrm{pH}$ using a GP-353 ATC $\mathrm{pH}$ meter equipped with an electrode from EDT Instrument, electrical conductivity using EDT instrument BA-380 conductivity meter and dissolved oxygen using CYPBER SCAN DO100-EUTECH instrument (DO meter). The Total Dissolved Solids (ppm) was calculated using the formula: TDS= conductivity $(\mathrm{mS} / \mathrm{cm}) \times 1000$ x 0.65 .

\section{Laboratory Analysis}

The trace amount of heavy metals in water samples $(\mathrm{Cu}, \mathrm{Cd}, \mathrm{Cr}, \mathrm{Pb}, \mathrm{Zn}, \mathrm{Fe}$ and $\mathrm{Mn})$ were estimated using Atomic Absorption Spectrophotometer. The standard curve for 
each heavy metal separately was done using clear heavy metals standards. Determination of heavy metals in seawater was done using the "Standard Methods for the Examination of Water and Waste Water - 1998" (Kransiqi, 2010). Results were shown on contour maps using 3D field and ArcGIS10.1-ESRI.

The ionic concentration of seawater was done by titration for Calcium, Magnesium and Chloride ions, by flame photometry for Sodium and Potassium ions and by spectrophotometer for Sulfate ions. In order to detect the presence of heterotrophic bacteria, streak plate method was used. 0.1 $\mathrm{ml}$ of water samples was streaked over nutrient agar plate and incubated at $37{ }^{\square} \mathrm{C}$ for 24 hours (Odokuma \& Okpokwasili, 1992 and APHA, 1998).

To detect the presence of Salmonella $s p$ or Shigella sp, $0.1 \mathrm{ml}$ aliquot of each water sample was spread using a sterile loop onto the surface $S \& S$ agar plates. The plates after inoculation were incubated in an inverted position $37{ }^{\square} \mathrm{C}$ for $24-48$ hours (APHA, 1998). Detection of Total and Fecal Coliform was done using Membrane Filtration technique. Water samples $(100 \mathrm{ml}$ each) were filtered using a Whatman filter paper $125 \mathrm{~mm}$ pore size to eliminate large particles, and then they were re-filtered using a Sartorius membrane filter $0.45 \mu \mathrm{m}$ pore size.

Filters were carefully transferred onto pads soaked in Lauryl sulphate bacterial broth and placed in pre-labeled sterilized Petri dishes. Incubate at $37 \mathrm{C}$ for 24 hours to detect the presence of total coliform, and at $44 \mathrm{C}$ for 24 hours to detect fecal coliforms (Hamzah et al., 1997, APHA 1998). After that the dishes were removed and filters were thoroughly examined using a colony counter to identify and count the colonies.
Calculation of Fecal Coliform was done according to the following formula:

Fecal Coliform per gram dry weight $=\frac{\text { Colonies counted } \times 100}{\text { volume of sample chosen }(\mathrm{ml})}$

\section{Sediments Analysis for Trace Metals (Pekey et al. 2004)}

\section{Sediment Digestion}

Dried and homogenized sediment $(0.5 \mathrm{~g})$ in a $50 \mathrm{ml}$ beaker was fortified with $5 \mathrm{ml}$ of concentrated nitric acid and the mixture was refluxed on hotplate for 5 to 10 minutes at approximately $95^{\circ} \mathrm{C}$. The beaker was allowed to cool then $2.5 \mathrm{ml}$ of concentrated nitric acid was added. The reflux was repeated until no brown fumes were observed.

The solution was evaporated to approximately $5 \mathrm{ml}$ at $95^{\circ} \mathrm{C}$ without boiling for one hour then was left to cool; then supplemented with $1 \mathrm{ml}$ water and $3 \mathrm{ml}$ of $30 \% \mathrm{H}_{2} \mathrm{O}_{2}$. The solution was then heated slowly to start the peroxide reaction. $30 \%$ of $\mathrm{H}_{2} \mathrm{O}_{2}$ was added in $1 \mathrm{ml}$ aliquots (less than a total of $10 \mathrm{ml}$ ) after cooling and repeated several times.

The acid-peroxide digestate was heated at $95^{\circ} \mathrm{C}$ without boiling for 1 hour. The beaker was then covered with a watch glass after the addition of $5 \mathrm{ml}$ of concentrated $\mathrm{HCl}$ and brought to heat on a hotplate at $95^{\circ} \mathrm{C}$ for 15 minutes. After heating is done, the digestate was cooled and transferred into a $50 \mathrm{ml}$ volumetric flask, diluted to $50 \mathrm{ml}$ with deionized water. The flask was then transferred to a $125 \mathrm{ml}$ high density polyethylene sample bottle for storage. Sample solutions analyzed for trace metals by atomic absorption spectroscopy. 
Assessment of Sediment Contamination by the Contamination Factor (Cif ) and Degree of Contamination $(\mathrm{Cd})$

Average shale values (Turekian and Wedepohl, 1961) and average crustal abundance (Taylor, 1972), are commonly used to provide elemental background concentrations (EBC) (Windom et al., 1989; Sanın et al., 1992; Covelli and Fontolan, 1997; Rubio et al., 2000). In the present study, Taylor's (1972) crustal abundance was used as reference baselines. A contamination factor $C_{\mathrm{f}}^{i}$ to describe the contamination of a given toxic substance in a basin was suggested by Hakanson (1980) equation 1 :

$C_{\mathrm{f}}^{i}=\frac{C_{0-1}^{i}}{C_{n}^{i}} \ldots \ldots \ldots \ldots \ldots \ldots \ldots \ldots$

Where,

$\bar{C}_{0-1}^{i}$ : the mean content of the substance $C_{n}^{i}$ : the reference value for the substance.

The following terminologies were used to describe the contamination factor:

$C_{\mathrm{f}}^{i}<1$; low contamination factor $1 \leq C_{\mathrm{f}}^{i}<3$; moderate contamination factors $3 \leq$ cfi $<6$; considerable contamination factors $C_{\mathrm{f}}^{i} \geq 6$; very high contamination factor

Degree of contamination $\left(\mathrm{C}_{\mathrm{d}}\right)$ defined as the sum of all contamination factors for a given basin. Equation 2 describes the contamination degree:

$C_{d}=\sum_{i=1}^{6} C_{\mathrm{f}}^{i}=\sum_{i=1}^{6} \frac{\bar{c}_{0-1}^{i}}{C_{n}^{i}} \ldots \ldots \ldots \ldots .2$

For the description of contamination degree the following terminologies were used:

$\mathrm{C}_{\mathrm{d}}<7$; low degree of contamination $7 \leq \mathrm{C}_{\mathrm{d}}<14$; moderate degree of contamination
$14 \leq \mathrm{C}_{\mathrm{d}}<28$; considerable degree of contamination

$\mathrm{C}_{\mathrm{d}} \geq 28$; very high degree of contamination

Ecotoxicological Sense of Trace Element Concentrations in Sediments (Pekey et al. 2004)

Numerical sediment quality guidelines (SQGs) have been used in North America for both freshwater and marine ecosystems, and have been used to identify contaminants of concern in aquatic ecosystems (MacDonald et al., 2000). Sampling and analytical processes may alter sediment chemistry and bioavailability. SQGs would then not reflect in-situ conditions absolutely. Assessment tools provide useful information, but some (i.e., SQGs, laboratory toxicity, bioaccumulation and benthic indices) are prone to distortion without the availability of specific in-situ exposure and effects data. Therefore, SQGs should be used only as a screening approach or in a weight-of-evidence method (Burton, 2002). Based upon empirical analyses of matching chemical and biological data, SQGs have been developed for many potentially toxic substances (i.e., trace elements, chlorinated organics, and polynuclear aromatic hydrocarbons (PAHs)) (Long and MacDonald, 1998; Long et al., 1998).

Two sets of SQGs developed for marine and estuarine ecosystems (MacDonald et al., 2000; Long and MacDonald, 1998) were applied in this study to assess the ecotoxicological sense of trace element concentrations in sediments (a) the effect rangelow (ERL)/effect range median (ERM) and (b) the threshold effect level (TEL)/probable effect level (PEL) values (Table 6).

Low range values (i.e., ERLs or TELs) are concentrations below which adverse effects 
upon sediment dwelling fauna would infrequent be expected. In contrast, the ERMs and PELs represent chemical concentrations above which adverse effects are likely to occur (Long and MacDonald, 1998). The incidence of toxicity was determined among samples in which none of the substances equaled or exceeded the ERL concentrations, in which one or increasing numbers of substances exceeded ERL concentrations, but none exceeded any ERM; and in which one or increasing numbers of substances exceeded ERM concentrations. The same approach was used to evaluate the predictive ability of the TELs/PELs (Long et al., 1998).

\section{Statistical Analysis}

Descriptive analysis was performed. Quantitative variables were described in terms of frequencies, mean, standard deviation, min and max. Paired correlations were performed between the studied parameters using Pearson's correlation coefficient. For testing the difference between the physical parameters and ion concentrations for summer and fall, paired sample t-test was used. The Type- 1 error $\alpha$ was set at $5 \%$. The analyses were performed using SPSS 17 for windows.

\section{Results and Discussion}

\section{Physico-Chemical Parameters}

\section{Temperature}

Temperature value recorded a decrease from June 2012 till November 2012 recording 24.3 and $24.2{ }^{\circ} \mathrm{C}$ respectively, this finding coincide with that stated by Abudaya \& Harara, 2013. These values were within the acceptable level for surviving metabolism and physiology of aquatic organisms (Lawson, 2011). Low temperature recorded in November 2012 may be due to high water level, less solar radiation, and low atmospheric temperature while in June the high temperature may be because of low water level, high solar radiation and clear atmosphere (Table 1) (Govindasamy et al., 2000).

\section{pH}

A significant decrease in the mean value of $\mathrm{pH}$ was depicted from June 2012 till November 2012, recording 8.1 and 7.8 respectively, ranging during June from 5.25 to 8.75 , and during November from 4.2 to 7.8 (Table 1). The present finding fell within the recommended value of $\mathrm{pH}$ of 8.2 (Quinby-Hurt \& Turekian, 1983 and Holmes, 2011). The lowest $\mathrm{pH}$ level was observed in the polluted sites, where a sewage input was found to be directly discharged into the sea. DOE( 2006) stated that the lowest $\mathrm{pH}$ level was observed in the most polluted sites, where a sewage input was found to be directly discharged into the sea, this finding complies with the results in the present study. Data of the present investigation coincide with that obtained with by Korfali \& Jurdi (2012) on the Lebanese coastal region concerning $\mathrm{pH}$ values ranging from 4-10 with a mean value of 7.85 .

\section{Dissolved Oxygen}

The dissolved oxygen's concentration in the study area showed some low levels during the study period. A significant increase in the DO concentration was noticed from June to November 2012 recording respectively 6.15 to $6.19 \mathrm{mg} / \mathrm{L}$ (Table 1) this increase maybe due to the cumulative effect of decreased temperature coupled with rainfall and the resultant freshwater mixing from runoffs (Rajasegar, 2003). The lowest levels were observed in sites heavily contaminated 
with sewage discharges. These observations are in agreement with Fargallah et al, (2009) who stated that heavy contamination causes an oxygen deficit due to decomposition of the organic matter. Similar finding was observed with Korfali \& Jurdi (2012) who reported that the DO level ranges from 1.2$8.8 \mathrm{mg} / \mathrm{L}$ for water quality study of Lebanon coastline.

\section{Electrical Conductivity and Total Dissolved Solids}

The electrical conductivity's average value recorded $98.8 \mathrm{mS} / \mathrm{cm}$ during June and $107.41 \mathrm{mS} / \mathrm{cm}$ during November. In June, TDS values ranged from 17355 and 975000 ppm, whereas in November TDS values ranged from 28015 to $1072500 \mathrm{ppm}$ with a mean value 75710.55 ppm (Table 1).

\section{Trace Metals Detection}

As for trace metals, a non significant variation was noticed in their concentration during the study period (Table 3). Results reported that trace metals' mean concentration during both sampling periods was higher than the guideline except for $\mathrm{Cr}$ whereas $\mathrm{Cu}, \mathrm{Cd}$ and $\mathrm{Pb}$ recorded mean values higher than the TRV (Table 2). Comparing these findings to the results obtained by Korfali and Jurdi (2012) in a study on trace metals in Lebanese coastal waters, it was revealed that the results of the present study fell within their ranges.

\section{Ionic Water Profile}

Chemical analysis of seawater samples has shown that the value of the concentrations of ions in non-contaminated areas are in accordance with the international standard for seawater and recorded in ppm $\mathrm{Na}^{+}, 12746$ \&15302; $\mathrm{K}^{+}, 430.2 \& \quad 389 ; \mathrm{Cl}^{-} \quad, \quad 23554$ $\& 22113 ; \mathrm{Ca}^{2+}, \quad 439$ \&512; $\mathrm{Mg}^{2+}, \quad 929$
\&1121; $\mathrm{SO}_{4}^{2-}, 2636$ \& 2576 (Table 4). Variations in concentration levels were observed in sites highly polluted by sewage discharges. These finding were in agreement with that of El Moujaber et al. (2006) who stated that seawater in general has a uniform chemistry due to a long residence time of major constituents with the predominance of $\mathrm{Cl}^{-}$and $\mathrm{Na}^{+}$possessing a molar ratio of 0.86. Seawater solutes are specifically characterized by an excess of $\mathrm{Cl}^{-}$over the cation ions $\left(\mathrm{Na}^{+}\right.$and $\left.\mathrm{K}^{+}\right), \mathrm{Mg}^{2+}, \mathrm{Ca}^{2+}$ and anion ion $\mathrm{SO}_{4}^{2-}$.

\section{Microbiological Analysis}

Results of microbiological analysis showed the presence of heterotrophic bacteria in all the seawater samples during June and November 2012. The presence of Salmonella sp. in seawater varied significantly during the 2 seasons. $60 \%$ of the samples were found positive for Salmonella sp during the summer season, while $55 \%$ were found positive during the fall season. Similarly, Shigella sp. was present in $33 \%$ of the sites during the summer season and $11 \%$ during the fall season.

Samples recorded 2200CFU/100ml total coliform (TC) during both sampling periods, which revealed a four folds increase than that of European guideline (Table 7). It was also revealed that $35 \%$ of the studied seawater samples were not suitable for swimming during June and $17 \%$ during November (Table 5). Fecal coliform (FC) counts recorded the highest value of $1800 \mathrm{CFU} / 100 \mathrm{ml}$ during November with $60 \%$ of the sites unsuitable for swimming (WHO guideline), whereas during June, $75 \%$ of the sites were classified unsuitable for swimming with the highest value recorded 1500CFU/100ml and (Table 7). 
Table.1 Description of the Physical Parameters of the Samples by Period ( $\mathrm{N}=45)$

\begin{tabular}{cccccc}
\hline $\begin{array}{c}\text { Physical } \\
\text { characteristics }\end{array}$ & Mean (SD) & $\begin{array}{c}\text { Jange } \\
\text { (Min;Max) }\end{array}$ & Mean (SD) & $\begin{array}{c}\text { November 2012 } \\
\text { Range } \\
\text { (Min;Max) }\end{array}$ & p-value \\
\hline $\begin{array}{c}\text { Temperature } \\
\left({ }^{\circ} \mathbf{C}\right)\end{array}$ & $24.3(0.3)$ & $(24.0 ; 25.0)$ & $24.2(0.2)$ & $(24.0 ; 24.8)$ & 0.035 \\
pH & $8.1(0.7)$ & $(5.2 ; 8.8)$ & $7.8(0.8)$ & $(4.2 ; 8.45)$ & $<0.0001$ \\
DO (mg/L) & $6.15(1.24)$ & $(1.38 ; 7.8)$ & $6.19(1.11)$ & $(2.01 ; 7.8)$ & 0.624 \\
E.C (ms/cm) & $98.8(269.1)$ & $(26.7 ; 1500)$ & $107.4(291.4)$ & $(43.1 ; 1650)$ & 0.019 \\
TDS (ppm) & 64230.1 & $(17355 ; 975000)$ & 75710.55 & $(28015 ; 1072500)$ & 0.071 \\
\hline
\end{tabular}

Table.2 TRV and Guidelines Values

\begin{tabular}{|c|c|c|c|c|c|c|c|}
\hline & Fe(mg/L) & Cu(mg/L) & Cd(mg/L) & Mn(mg/L) & $\operatorname{Zn}(\mathbf{m g} / \mathbf{L})$ & $\mathrm{Cr}(\mathrm{mg} / \mathrm{L})$ & $\operatorname{Pb}(\mathrm{mg} / \mathrm{L})$ \\
\hline TRV & $\mathbf{1 . 0 0 0}$ & $\mathbf{0 . 0 0 6 5 4}$ & $\mathbf{0 . 0 0 0 6 6}$ & $\mathbf{0 . 1 2 0}$ & $\mathbf{0 . 1 2 0}$ & $\mathbf{0 . 1 1 7}$ & $\mathbf{0 . 0 0 1 3 2}$ \\
\hline Guideline & $\mathbf{0 . 0 0 0 1 4}$ & $\mathbf{0 . 0 0 0 3 8}$ & $\mathbf{0 . 0 0 0 1 2 5}$ & $\mathbf{0 . 0 0 0 1 6 5}$ & $\mathbf{0 . 0 0 0 5 9}$ & $\mathbf{0 . 0 0 0 2 6}$ & $\mathbf{0 . 0 0 0 0 3 6}$ \\
\hline
\end{tabular}

Table.3 Description of the Trace Metal Concentration in the Samples by Period (N=45)

\begin{tabular}{cccccc}
\hline $\begin{array}{c}\text { Physical } \\
\text { characteristics }\end{array}$ & Mean (SD) & $\begin{array}{c}\text { June 2012 } \\
\text { Rin;Max) }\end{array}$ & Mean (SD) & $\begin{array}{c}\text { November 2012 } \\
\text { (Min;Max) }\end{array}$ & p-value \\
\hline Iron & $0.0487(0.105)$ & $(0.001 ; 0.5)$ & $0.0442(0.085)$ & $(0 ; 0.35)$ & 0.508 \\
Copper & $0.049(0.039)$ & $(0.001 ; 0.15)$ & $0.049(0.037)$ & $(0.001 ; 0.13)$ & 0.445 \\
Cadmium & $0.004(0.011)$ & $(0 ; 0.05)$ & $0.001(0.004)$ & $(0 ; 0.03)$ & 0.085 \\
Manganese & $0.082(0.194)$ & $(0.001 ; 1.2)$ & $0.089(0.178)$ & $(0 ; 0.9)$ & 0.878 \\
Zinc & $0.039(0.0099)$ & $(0.018 ; 0.060)$ & $0.037(0.01179)$ & $(0.01 ; 0.06)$ & 0.041 \\
Chromium & $0.00006(0.00033)$ & $(0 ; 0.02)$ & $0.0003(0.00146)$ & $(0 ; 0.007)$ & 0.234 \\
Lead & $0.210(0.1538)$ & $(0 ; 0.660)$ & $0.215(0.1453)$ & $(0 ; 0.520)$ & 0.802 \\
\hline
\end{tabular}

Table.4 Description of the Ion Composition of the Samples by Period ( $\mathrm{N}=45)$

\begin{tabular}{lccccc}
\hline & \multicolumn{2}{c}{ June 2012 } & \multicolumn{2}{c}{ November 2012 } & p-value \\
$\begin{array}{l}\text { Ions' concentration } \\
(\mathbf{p p m})\end{array}$ & Mean (SD) & $\begin{array}{c}\text { Range } \\
\text { (Min;Max) }\end{array}$ & Mean (SD) & $\begin{array}{c}\text { Range } \\
\text { (Min;Max) }\end{array}$ & \\
\hline $\mathbf{N a}^{+}$ & $12678.2(974)$ & $(11120 ; 15600)$ & $12746.7(1248.9)$ & $(8480 ; 16000)$ & 0.642 \\
$\mathbf{K}^{+}$ & $389.3(62.8)$ & $(244.4 ; 560.4)$ & $430.2(74.6)$ & $(244.4 ; 560.4)$ & 0.001 \\
$\mathbf{C l}^{-}$ & $22926.2(2395.9)$ & $(12000 ; 26400)$ & $23554.2(5667)$ & $(310 ; 28570)$ & 0.481 \\
$\mathbf{C a}^{2+}$ & $512.8(49.1)$ & $(268 ; 552)$ & $439.1(95.3)$ & $(120 ; 630)$ & $<0.0001$ \\
$\mathbf{M g}^{2+}(\mathbf{p p m})$ & $1121.9(154.4)$ & $(250 ; 1310)$ & $929.7(391.3)$ & $(82 ; 1227)$ & $<0.0001$ \\
$\mathbf{S O}_{\mathbf{4}}^{2-}(\mathbf{p p m})$ & $2576(474.2)$ & $(1000 ; 3540)$ & $2636.1(446.1)$ & $(1500 ; 3912)$ & 0.396 \\
\hline
\end{tabular}

Table.5 Microbiological Standards for Marine Bathing Water (European Union, 2005)

\begin{tabular}{lcc}
\hline & European Guide & European Mandatory \\
\hline Total Coliforms & $500 \mathrm{CFU} / 100 \mathrm{~mL}$ & $10,000 \mathrm{CFU} / 100 \mathrm{~mL}$ \\
\hline Fecal Coliforms & $100 \mathrm{CFU} / 100 \mathrm{~mL}$ & $2,000 \mathrm{CFU} / 100 \mathrm{~mL}$ \\
\hline
\end{tabular}


Table.6 Quality of Water for Swimming* (WHO, 2006)

\begin{tabular}{cc}
\hline Water quality & E.coli $($ count $/ \mathbf{m l})$ \\
\hline Very bad & $>2000$ \\
Middle pollution & $1000-2000$ \\
Soft pollution & $50-200$ \\
Very satisfying & $<50$ \\
\hline
\end{tabular}

Table.7 Description of the Bacterial Counts in the Seawater Sample by Period $(\mathrm{N}=45)$

\begin{tabular}{c|cc|ccc}
\hline & \multicolumn{3}{|c}{ June 2012 } & \multicolumn{2}{c}{ November 2012 } \\
\hline Bacterial count (CFU/100ml) & Mean (SD) & Range (Min;Max) & Mean (SD) & Range (Min;Max) & $\begin{array}{c}\text { p- } \\
\text { value }\end{array}$ \\
\hline Total Coliform & $537(571.4)$ & $(25 ; 2200)$ & $463(656)$ & $(40 ; 2200)$ & 0.22 \\
Fecal Coliform & $327(352)$ & $(10 ; 1500)$ & $289(419)$ & $(10 ; 1800)$ & 0.249 \\
\hline
\end{tabular}

Table.8 Correlation Matrix Between Physical and Bacteriological Parameters during June 2012

\begin{tabular}{|c|c|c|c|c|c|c|c|c|}
\hline & & Temperature & $\mathbf{p H}$ & $\begin{array}{c}\text { DO } \\
(\mathrm{mg} / \mathrm{L})\end{array}$ & $\begin{array}{c}E C \\
(m s / c m)\end{array}$ & $\begin{array}{c}\text { TDS } \\
\text { (ppm) }\end{array}$ & $\begin{array}{c}\text { Total } \\
\text { coliform }\end{array}$ & $\begin{array}{l}\text { Fecal } \\
\text { seliform }\end{array}$ \\
\hline Temperature & $\begin{array}{l}\text { PCorrelation } \\
\text { Sig.(2-tailed) }\end{array}$ & 1 & & & & & & \\
\hline рн & $\begin{array}{l}\text { PCorrelation } \\
\text { sig.(2-tailed) }\end{array}$ & $\begin{array}{r}. .536^{-} \\
.000 \\
\end{array}$ & 1 & & & & & \\
\hline DO $(\mathrm{mg} / \mathrm{L})$ & $\begin{array}{l}\text { PCorrelation } \\
\text { Sig.(2-tailed) }\end{array}$ & $\begin{array}{r}. .475^{-} \\
.001 \\
\end{array}$ & $\begin{array}{r}.733^{-} \\
.000 \\
\end{array}$ & 1 & & & & \\
\hline$E C(m s / c m)$ & $\begin{array}{l}\text { PCorrelation } \\
\text { Sig.(2-tailed) }\end{array}$ & $\begin{array}{r}.498^{-} \\
.000 \\
\end{array}$ & $\begin{array}{r}-.841^{-} \\
.000 \\
\end{array}$ & $\begin{array}{r}-.492^{-} \\
.001 \\
\end{array}$ & 1 & & & \\
\hline TDS (ppm) & $\begin{array}{l}\text { PCorrelation } \\
\text { sig.(2-tailed) }\end{array}$ & $\begin{array}{r}.498^{-} \\
.000 \\
\end{array}$ & $\begin{array}{r}.841^{-} \\
.000 \\
\end{array}$ & $\begin{array}{r}-.492^{-} \\
.001 \\
\end{array}$ & $\begin{array}{r}1.000^{-} \\
.000 \\
\end{array}$ & 1 & & \\
\hline Total celiform & $\begin{array}{l}\text { PCorrelation } \\
\text { Sig.(2-tailed) }\end{array}$ & $\begin{array}{l}.318^{-} \\
.033 \\
\end{array}$ & $\begin{array}{r}-.646^{-} \\
.000 \\
\end{array}$ & $\begin{array}{r}-.866^{-} \\
.000 \\
\end{array}$ & $\begin{array}{r}.468^{-} \\
.001 \\
\end{array}$ & $\begin{array}{r}.468^{-} \\
.001 \\
\end{array}$ & 1 & \\
\hline Fecal coliform & $\begin{array}{l}\text { PCorrelation } \\
\text { Sig.(2-tailed) }\end{array}$ & $\begin{array}{l}.280 \\
.062 \\
\end{array}$ & $\begin{array}{r}-.674^{-} \\
.000\end{array}$ & $\begin{array}{r}-.871^{-} \\
.000\end{array}$ & $\begin{array}{r}.442^{-} \\
.002 \\
\end{array}$ & $\begin{array}{r}.442^{-} \\
.002 \\
\end{array}$ & $\begin{array}{r}.928^{-} \\
.000\end{array}$ & 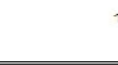 \\
\hline
\end{tabular}

* . Correlation is significant at the 0.01 level (2-tailed)

*. Correlation is significant at the 0.05 level (2-tailed).

Table.9 Correlation Matrix between Physical and Bacteriological Parameters during November 2012

\begin{tabular}{|c|c|c|c|c|c|c|c|c|}
\hline & & Temperature & pH & $\begin{array}{c}\mathrm{DO} \\
(\mathrm{mg} / \mathrm{L})\end{array}$ & $\begin{array}{c}\mathrm{EC} \\
(\mathrm{ms} / \mathrm{cm})\end{array}$ & $\begin{array}{c}\text { TDS } \\
\text { (ppom) }\end{array}$ & $\begin{array}{c}\text { Total } \\
\text { coliform }\end{array}$ & $\begin{array}{c}\text { Fecal } \\
\text { coliform }\end{array}$ \\
\hline Temperature & $\begin{array}{l}\text { P Correlation } \\
\text { Sig. (2-tailed) }\end{array}$ & 1 & & & & & & \\
\hline pH & $\begin{array}{l}\text { P Correlation } \\
\text { Sig. (2-tailed) }\end{array}$ & $\begin{array}{r}-.049 \\
.748 \\
\end{array}$ & 1 & & & & & \\
\hline DO (mg/L) & $\begin{array}{l}\text { P Correlation } \\
\text { Sig. (2-tailed) }\end{array}$ & $\begin{array}{r}-.052 \\
.736 \\
\end{array}$ & $\begin{array}{c}.741^{-} \\
.000 \\
\end{array}$ & 1 & & & & \\
\hline EC & $\begin{array}{l}\text { P Correlation } \\
\text { Sig. (2-tailed) }\end{array}$ & $\begin{array}{r}-.026 \\
.866 \\
\end{array}$ & $\begin{array}{r}-.770^{-} \\
.000 \\
\end{array}$ & $\begin{array}{r}-.637^{-} \\
.000 \\
\end{array}$ & 1 & & & \\
\hline TDS & $\begin{array}{l}\text { P Correlation } \\
\text { Sig. (2-tailed) }\end{array}$ & $\begin{array}{r}-.062 \\
.684 \\
\end{array}$ & $\begin{array}{r}-.744^{-} \\
.000 \\
\end{array}$ & $\begin{array}{r}-.597^{-} \\
.000 \\
\end{array}$ & $\begin{array}{l}.979^{-} \\
.000 \\
\end{array}$ & 1 & & \\
\hline $\begin{array}{c}\text { Total } \\
\text { coliform }\end{array}$ & $\begin{array}{l}\text { P Correlation } \\
\text { Sig. (2-tailed) }\end{array}$ & $\begin{array}{r}-.010 \\
.949 \\
\end{array}$ & $\begin{array}{r}-.662^{-} \\
.000 \\
\end{array}$ & $\begin{array}{r}-.842^{-} \\
.000 \\
\end{array}$ & $\begin{array}{l}.568^{-} \\
.000\end{array}$ & $\begin{array}{l}.542^{-} \\
.000\end{array}$ & 1 & \\
\hline $\begin{array}{l}\text { Fecal } \\
\text { coliform }\end{array}$ & $\begin{array}{l}\text { P Correlation } \\
\text { Sig. (2-tailed) }\end{array}$ & $\begin{array}{c}-.010 \\
.947 \\
\end{array}$ & $\begin{array}{r}-.737^{-} \\
.000\end{array}$ & $\begin{array}{r}-.832^{-} \\
.000\end{array}$ & $\begin{array}{l}.555^{-} \\
.000\end{array}$ & $\begin{array}{l}.528^{-} \\
.000 \\
\end{array}$ & $\begin{array}{l}.956^{-} \\
.000\end{array}$ & 1 \\
\hline
\end{tabular}


Table.10 Elemental Concentration from Surface Sediments and SQG by US EPA

\begin{tabular}{|c|c|c|c|c|}
\hline & & \multicolumn{3}{|c|}{ Element } \\
\hline & & $\mathbf{P b}$ & Zn & $\mathbf{C u}$ \\
\hline \multirow{24}{*}{ 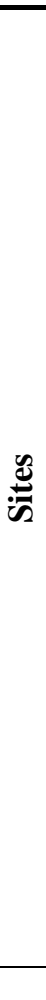 } & 1 & 12 & 8 & 2.3 \\
\hline & 2 & 10 & 6 & 2.8 \\
\hline & 3 & 21 & 12 & 2.3 \\
\hline & 4 & 10 & 7 & 2.8 \\
\hline & 5 & 12 & 6 & 3.7 \\
\hline & 6 & 11 & 7 & 3.9 \\
\hline & 7 & 10 & 10 & 4.2 \\
\hline & 8 & 11 & 9 & 4.6 \\
\hline & 9 & 11 & 6 & 4.4 \\
\hline & 10 & 15 & 5 & 4.4 \\
\hline & 11 & 10 & 8 & 3 \\
\hline & 12 & 11 & 8 & 3 \\
\hline & 13 & 8 & 9 & 4 \\
\hline & 14 & 8 & 9 & 2.6 \\
\hline & 15 & 10 & 35 & 2.5 \\
\hline & 16 & 11 & 29 & 2.6 \\
\hline & 17 & 11 & 7 & 2 \\
\hline & 18 & 12 & 6 & 2.5 \\
\hline & 19 & 11 & 4 & 4 \\
\hline & 20 & 12 & 8 & 3.9 \\
\hline & 21 & 11 & 6 & 3.9 \\
\hline & 22 & 12 & 26 & 28 \\
\hline & 23 & 15 & 38 & 13 \\
\hline & EBC & 12.5 & 70 & 55 \\
\hline \multirow{3}{*}{ ర్ల } & NP & $<40$ & $<90$ & $<25$ \\
\hline & MP & $40-60$ & $90-200$ & $25-50$ \\
\hline & HP & $>60$ & $>20$ & $>50$ \\
\hline
\end{tabular}

EBC: Elemental Background concentration

SQG: Sediment quality guidelines

NP: non-polluted

MP: moderately polluted

HP: heavily polluted

Fig.1 Geographical Distribution of the Water Sampling Sites

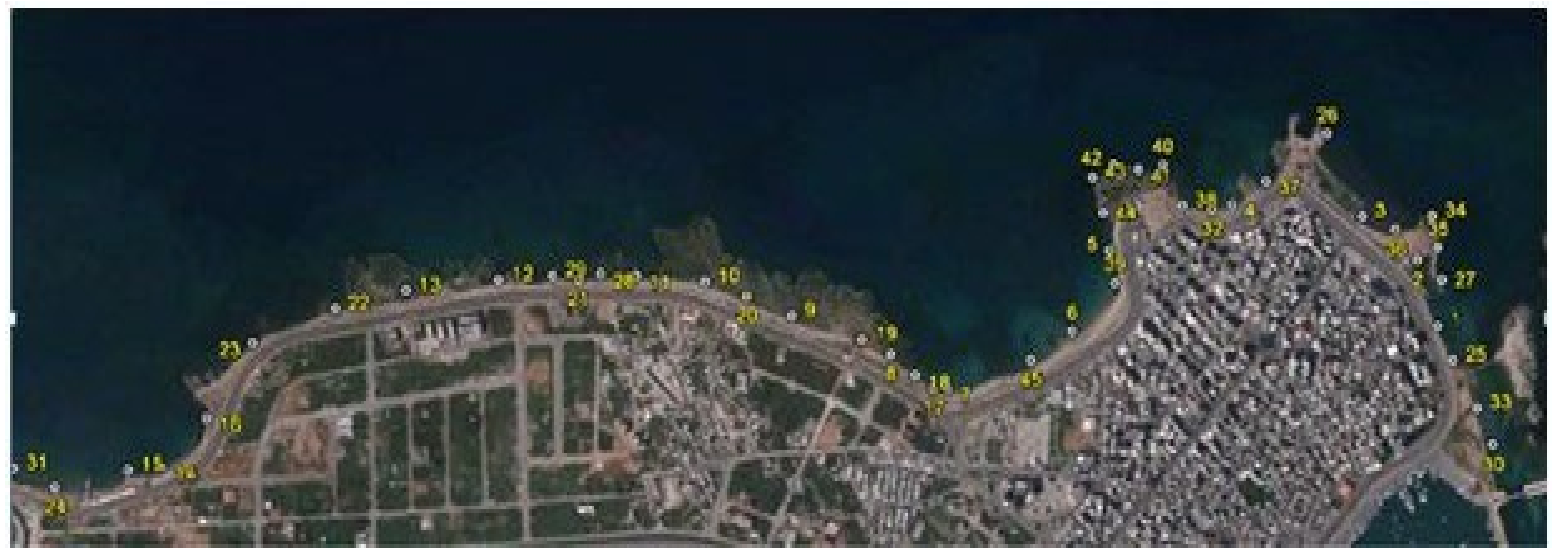


Table.11 Contamination Factors $\left(C_{-} f^{\wedge} \mathrm{i}\right)$ and Degree of Contamination $\left(C_{-} d\right)$ of Surface Sediments in Mina City Coastline during June 2012

\begin{tabular}{c|ccc|c}
\hline & & $\boldsymbol{C}_{\boldsymbol{f}}^{\boldsymbol{i}}$ & & $\boldsymbol{C}_{\boldsymbol{d}}$ \\
\hline Site & $\mathbf{P b}$ & $\mathbf{Z n}$ & $\mathbf{C u}$ & 1.11 \\
\hline 1 & 0.96 & 0.11 & 0.04 & 0.93 \\
2 & 0.8 & 0.08 & 0.05 & 1.89 \\
3 & 1.68 & 0.17 & 0.04 & 0.95 \\
4 & 0.8 & 0.1 & 0.05 & 1.1 \\
5 & 0.96 & 0.08 & 0.06 & 1.05 \\
6 & 0.88 & 0.1 & 1.01 \\
7 & 0.8 & 0.14 & 0.07 & 1.08 \\
8 & 0.88 & 0.12 & 0.07 & 1.04 \\
9 & 0.88 & 0.08 & 1.35 \\
10 & 1.2 & 0.07 & 0.08 & 0.96 \\
11 & 0.8 & 0.11 & 0.08 & 1.04 \\
12 & 0.88 & 0.11 & 0.83 \\
13 & 0.64 & 0.12 & 0.05 & 0.8 \\
14 & 0.64 & 0.12 & 0.07 & 1.34 \\
15 & 0.8 & 0.5 & 0.04 & 1.33 \\
16 & 0.88 & 0.41 & 0.04 & 1.01 \\
17 & 0.88 & 0.1 & 0.04 & 1.08 \\
18 & 0.96 & 0.08 & 0.03 & 1 \\
19 & 0.88 & 0.05 & 0.04 & 1.14 \\
20 & 0.96 & 0.11 & 0.07 & 1.03 \\
21 & 0.88 & 0.08 & 0.07 & 1.83 \\
22 & 0.96 & 0.37 & 0.07 & 1.97 \\
23 & 1.2 & 0.54 & 0.5 & 0.8 \\
Min & 0.64 & 0.05 & 0.23 & 1.97 \\
max & 1.68 & 0.54 & 0.03 & 7 \\
Reference & 1 & 1 & 1 & \\
\hline
\end{tabular}

Fig.2 Geographical Distribution of the Sediment Sampling Sites

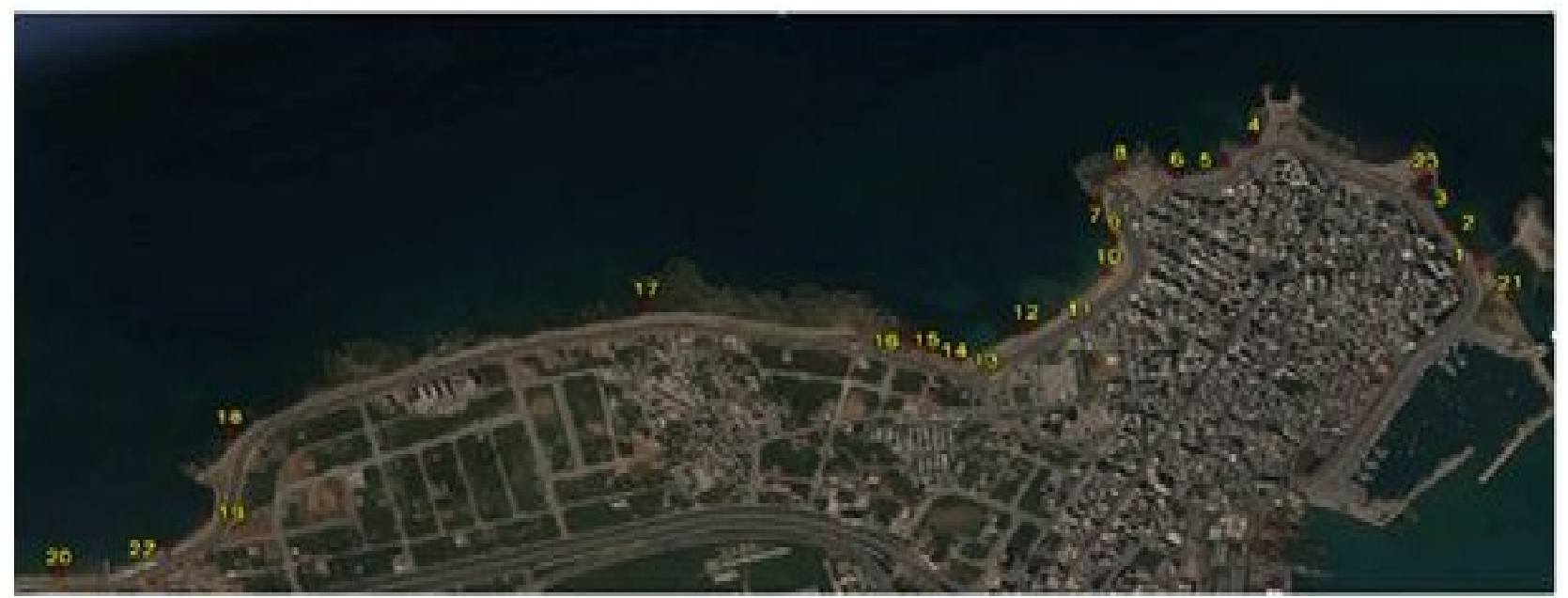


Table.12 TEL, PEL, ERL and ERM Guideline Values for Trace Elements (Long et al. (1995). Concentrations are in $\mathrm{lg} / \mathrm{g}$ Dry Weight)

\begin{tabular}{|c|c|c|c|c|}
\hline & & & Elem & \\
\hline & & $\mathbf{P b}$ & Zn & $\mathbf{C u}$ \\
\hline & 1 & 12 & 8 & 2.3 \\
\hline & 2 & 10 & 6 & 2.8 \\
\hline & 3 & 21 & 12 & 2.3 \\
\hline & 4 & 10 & 7 & 2.8 \\
\hline & 5 & 12 & 6 & 3.7 \\
\hline & 6 & 11 & 7 & 3.9 \\
\hline & 7 & 10 & 10 & 4.2 \\
\hline & 8 & 11 & 9 & 4.6 \\
\hline & 9 & 11 & 6 & 4.4 \\
\hline & 10 & 15 & 5 & 4.4 \\
\hline & 11 & 10 & 8 & 3 \\
\hline 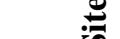 & 12 & 11 & 8 & 3 \\
\hline & 13 & 8 & 9 & 4 \\
\hline & 14 & 8 & 9 & 2.6 \\
\hline & 15 & 10 & 35 & 2.5 \\
\hline & 16 & 11 & 29 & 2.6 \\
\hline & 17 & 11 & 7 & 2 \\
\hline & 18 & 12 & 6 & 2.5 \\
\hline & 19 & 11 & 4 & 4 \\
\hline & 20 & 12 & 8 & 3.9 \\
\hline & 21 & 11 & 6 & 3.9 \\
\hline & 22 & 12 & 26 & 28 \\
\hline & 23 & 15 & 38 & 13 \\
\hline & ERL & 46.7 & 150.0 & 34.0 \\
\hline$\overline{0}$ & ERM & 218.0 & 410.0 & 270.0 \\
\hline & TEL & 30.2 & 124.0 & 18.7 \\
\hline 0 & PEL & 112.2 & 271.0 & 108.2 \\
\hline
\end{tabular}

The two bacterial types exhibited marked spatial and temporal variations. These findings were in accordance with the results found by Abudaya \& Hararah (2013), who have studied the physico-chemical parameters and faecal indicators at selected sites on the Gaza coast over seven-month period, their results showed spatial and temporal variations in physico-chemical parameters (water temperature, turbidity, $\mathrm{pH}$, salinity and DO), and fecal indicators that appeared linked with the problems of raw sewage discharge and storm water runoff. The data indicates high microbiological contamination of seawater above internationally accepted limits, especially at stations close to sewage outlet, which violates the European Countries standards for bathing water, this finding coincide with the study of Abudaya \& Hararah (2013).

Correlation Relation between the Physico-Chemical Parameters and the Microbial Pollution Load

Statistical analysis was done to reveal the relation between the bacterial load and the phyico-chemical parameters of the seawater samples. Results shown in table 8 recorded that during June TC and FC are strongly correlated having $(\mathrm{r}=0.928$ at $\mathrm{p}<0.001)$. TC load was positively correlated with $\mathrm{T}$, EC and TDS, with Pearson's correlation 
coefficient of $0.318 \quad(\mathrm{p}=0.033, \mathrm{p}<0.05)$, $0.468 \quad(\mathrm{p}=0.001 ; \mathrm{p}<0.01)$ respectively. Whereas, TC showed a negative correlation with $\mathrm{DO}$ and $\mathrm{pH}$, with $\mathrm{r}=-0.866(\mathrm{p}<0.0001)$ and $0.646(\mathrm{p}=-0.003 ; \mathrm{p}<0.01)$ respectively. However, FC also showed positive correlation with T, EC and TDS having with $\mathrm{r}=0.28(\mathrm{p}=0.062)$, and $0.442(\mathrm{p}=0.002$; $\mathrm{p}<0.01)$ respectively. $\mathrm{pH}$ and $\mathrm{DO}$, showed a negative correlation with $\mathrm{FC}$, with $\mathrm{r}=-0.647$ and 0.871 respectively. Data in table 9, revealed that, during November TC and FC showed a strong positive correlation, with a correlation coefficient $r=0.956(p<0.0001)$. TC showed a strong positive correlation with EC and TDS with $r=0.568$. TC showed a non significant weak negative correlation with $\mathrm{T}(\mathrm{r}=-0.01$ at $\mathrm{p}=0.949)$, strong negative correlation with $\mathrm{pH}(\mathrm{r}=$ 0.662 at $\mathrm{p}<0.0001$ ), and a strong negative correlation with DO $(r=-0.842)$. FC showed a positive correlation with EC and TDS, having correlation coefficient of 0.555 at $\mathrm{p}<0.0001$, and a strong negative correlation coefficient with $\mathrm{pH}$ and $\mathrm{DO}$, respectively $\mathrm{r}=$ -0.737 and $r=-0.832$, and a non significant weak negative correlation with $\mathrm{T}$ having $\mathrm{r}=$ -0.01 at $\mathrm{p}=0.947 . \quad(\mathrm{p}<0.0001)$ and $\mathrm{r}=0.618$ $(\mathrm{p}<0.0001)$. TC showed an intermediate correlation coefficient with $\mathrm{Zn}$ of $\mathrm{r}=0.360$ $(p=0.015, p<0.05)$, whereas it showed a nonsignificant weak negative correlation with copper, of $r=-0.091$. On the other hand, FC showed a strong positive.

\section{Trace Metals Concentrations in Sediments Samples}

The risk assessment was evaluated by detecting the concentration of trace metals in the sediments. 3 out of 23 sites showed high value of contamination factor whereas the rest of the elements showed average values below the guideline (Tables 10). $\mathrm{Pb}$ concentration ranged from 8-21 $\mu \mathrm{g}, \mathrm{Zn}$ concentrations ranged from 4 to $38 \mu \mathrm{g}$ and
$\mathrm{Cu}$ concentration ranged from 2-28 $\mu \mathrm{g}$. The most polluted areas were at sites 22 and 23 . Sediments were classified as: non-polluted (NP) based on the SQG (sediment quality guidelines) of US EPA.

\section{Assessment of Sediment Contamination by the Contamination Factor $\left(C_{f}^{i}\right)$ and Degree of Contamination $\left(\mathbf{C}_{d}\right)$}

The contamination factor $\left(C_{\mathrm{f}}^{i}\right)$ and the contamination degree $\left(\mathrm{C}_{\mathrm{d}}\right)$ recorded average levels for $\mathrm{Pb}, \mathrm{Cu}$ and $\mathrm{Zn}$ (Table 11). Lead contamination factor $\left(C_{\mathrm{f}}^{i}\right)$ ranged from 0.64 to 1.68 , sites 2,10 and 23 only exceeded the reference value; whereas that of $\mathrm{Zn}$, ranged from 0.05 to 0.54 and $\mathrm{Cu}$, from 0.81 to 1.97 , both did not exceed the reference value. The contamination degree values provided in Table 11 revealed low degree of contamination. Considering the results, given in Table 12 the trace metal concentrations in sediments were below the ERL, and TEL values suggesting a minimal effect range or an effect rarely observed.

In conclusion, results of this study reflect on continuous exposure of the coastal line to various types of contaminants resulting from, mostly, domestic and industrial activities. As such, the water quality profile and metal speciation is expected to impact the quality of seawater, aquatic organisms and consequently human health. Thus, it is critical to implement the recommended intervention plans to safe guard the "Mediterranean Sea" in accordance with international treaties and conventions.

\section{References}

Abuday, M. and Hararah, S. (2013). Spatial and Temporal Variations in Water Quality along the Coast of Gaza Strip. Journal of Environment and Earth Science. 3:2. 
Adefemi, S. and Awokunmi, E. (2010). Determination of physico-chemical parameters and heavy metals in water samples from Itaogbolu area of OndoState, Nigeria. African Journal of Environmental Science and Technology. 4.3: 145-148.

American Public health Association APHA, (1998). Standard methods for the examination of water and wastewater. Washington D.C.18:8755-3546.

ASTM, (1990). Guide for collection, storage, characterization and manipulation of sediments for toxicological testing. American Society for testing materials PH USAC. 1:971.

Awad, M. and Darwich, T. (2009). Evaluating sea water quality in the coastal zone of the north Lebanon using telemac2DTM. Lebanese Science Journal. 1:3543.

Burton Jr., G. (2002). Sediment quality criteria in use around the world. Limnology. 3: $65-75$.

Covelli, S. and Fontolan, G. (1997). Application of a normalization procedure in determining regional geochemical baselines. Environmental Geology. 30:34-45.

El Moujaber, M.; Bou Samra, B.; Darwish, T.; Atallah, T. (2006). Comparison of different indicators for groundwater contamination by seawater intrusion on the Lebanese coast. Water Resource Management. 20:161-180.

Faragallah, H; Askar, A.; Okbah, M. and Moustafa M. (2009). Physico-chemical characteristics of the open Mediterranean sea water far about 60 $\mathrm{Km}$ from Damietta harbor, Egypt. Journal of Ecology and The Natural Environment.1(5):106-119.

Govindasamy, C.; Kannan, L. and Azariah, J. (2000). Seasonal variation in Physicochemical properties and primary production in the coastal water biotopes of Coromandel Coast. India journal of environmental biology. 21: 1-7.

Hakanson, L. (1980). Ecological risk index for aquatic pollution control. A sedimentological approach. Water Research. 14:975-1001.

Hamza, A.; Abdullah, M.; Sarmani, S. and Jouhari, M. (1997). Chemical and bacteriological monitoring of drinking water from an urbanized water catchment drainage basin. Environ. Monit. Asses. 44: 327-328.

Holmes-Farley, R. (2011). Reef Alchamy:What is Seawater Reef Central Online Community http://reefkeeping.com/issues/2005 $11 /$ rhfindex.php.

Korfali, S. and Jurdi, M. (2012). Chemical Profile of Lebanon's Potential Contaminated Coastal Water Journal of Environmental Science and Engineering.1: 351-363.

Krahn, M.; Myers, M.; Burrows, D. and Malins, D. (1984). Determination of metabolites of xenobiotics in the bile of fish from polluted waterways. Xenobiotica.14 (8): 633-646.

Krasniki, K.; Krasniki, I.; Vasjari, M.; Sefaja, L. and Zuka, A. (2010). The level of heavy metals in several alternative water sources in the area kastriot-VushtrriDrenas. Ohrid. 25-29.

Lawson, E. (2011). Physico-Chemical Parameters and Heavy Metal Contents of Water from the Mangrove Swamps of Lagos Lagoon, Lagos, Nigeria. Advances in Biological Research 5. 1: $08-21$.

Lees, D. (2000) .Viruses and bivalve shellfish. Int J Food Microbiol. 59: 81-116.- Lipp, E.; Kurz, R.; Vincent, R.; RodriguezPalacios, C.; Farrah, S. and Rose, J. (2001). The effects of seasonal variability and weather on microbial fecal pollution and enteric pathogens in a sub-tropical estuary. Estuaries. 24:238-258.

Long, E. and MacDonald, D. (1998). Recommended uses of empirically derived, sediment quality guidelines for marine and estuarine ecosystems. Human and Ecological Risk 
Assessment. 4(5): 1019- 1039.

Long, E.; Field, L. and MacDonald, D. (1998). Predicting toxicity in marine sediments with numerical sediment quality guidelines. Environmental Toxicology and Chemistry. 17 (4):714-727.

MacDonald, D.; Ingersoll, C. and Berger, T. (2000.) Development and evaluation of consensus-based sediment quality guidelines for freshwater ecosystems. Archives of Environmental Contamination and Toxicology. 39:2031.

Mansilha, C.; Coelho, C.; Heitor, A.; Amado, J.; Martins, J. and Gameiro, P. (2009). Bathing waters: New directive, new standards, new quality approach. Marine Pollution Bulletin. 58:1562-1565.Odokuma, L. and Okpokwasili, G. (1992). Role of Composition in Degradability of Oil spill Dispersants. Waste. manage.590-660.

Öztürk, M.; Özözen,G.; Minareci, O. and Minareci, E.(2009). Determination of heavy metals in fish, water and sediments of Avsar Dam Lake in Turkey. Iran. J. Environ. Health. Sci. Eng.6(2):73-80.

Pekey, H.; Karakas, D.; Ayberk, S.; Tolun, L. and Bakoglu, M. (2004). Ecological risk assessment using trace elements from surface sediments of Izmit Bay (Northeastern Marmara Sea) Turkey Marine Pollution Bulletin. 48:946-953.

Quinby-Hunt, M. and Turekian, K. (1983). Distribution of elements in sea water.
EOS Transactions American Geophysical Union.64:130-131.

Rajasegar, M.(2003). Physico-chemical characteristics of the Vellar estuary in relation to shrimp farming. J. Environ. Biol., 24 95-101.

Rubio, B.; Nombela, M. and Vilas, F. (2000). Geochemistry of major and trace elements in sediments of the Ria de Vigo (NW Spain): an assessment of metal pollution. Marine Pollution Bulletin 40. (11):968-980.

Sanın, S.; Tuncel, G.; Gaines, A.F. and Balkas, T.I. (1992). Concentrations and distributions of some major and minor elements in the sediments of River Geoksu and Tasucu Delta, Turkey. Marine Pollution Bulletin. 24 (3):167169.

Taylor, S. (1972). Abundance of chemical elements in the continental crust; a new table. Geochimica Cosmochimica Acta. 28:1273.

Turekian, K. and Wedepohl, K. (1961). Distribution of the elements in some major units of the earth's crust. Geological Society of America Bulletin. 72:175-192.

Windom, H.; Schropp, S.; Calder, F.; Ryan, J.; Smith, R.; Burney, L. Lewis, F. and Rawlinson, C. (1989). Natural trace metal concentrations in estuarine and coastal marine sediments of the Southeastern United States. Environmental Science and Technology. 23 (3):314-320.

\section{How to cite this article:}

El Fallah, R., Z. Olama and H. Holail. 2016. Marine Quality Assessment of Northern Lebanese Coast: Microbiological and Chemical Characteristics and their Impact on the Marine Ecosystem. 2016. Int.J.Curr.Microbiol.App.Sci. 5(1): 376-389 ihttp://dx.doi.org/10.20546/ijcmas.2016.501.035 